UDC 553.493; 550.93

O. Hrinchenko', PhD (Geol.-Min.), Assoc. Prof., E-mail: alexgrin@univ.kiev.ua

S. Bondarenko², PhD (Geol.), Senior Researcher E-mail: sbond@igmof.gov.ua

T. Mironchuk', PhD (Philol.), Assoc. Prof.

E-mail: tatianakiev99@gmail.com

${ }^{1}$ Taras Shevchenko National University of Kyiv, Institute of Geology 90 Vasylkivska Str., Kyiv, 03022, Ukraine

${ }^{2}$ Institute of Geochemistry, Mineralogy and Ore Formation, NAS of Ukraine 34 Palladina Ave., Kyiv-142, 03680, Ukraine

\title{
GRANITOIDS, RARE-METAL PEGMATITES AND TA-NB MINERALIZATION OF SHPOLIANO-TASHLYK ORE AREA (INGUL MEGABLOCK, UKRAINIAN SHIELD)
}

\begin{abstract}
(Рекомендовано членом редакційної колегії д-ром геол.-мінералог. наук, проф. В.М. Загнітком)
Composition of granites, genetically associated pegmatites and superimposed metasomatites distributed within Shpoliano-Tashlyk ore area (Ingul megablock) is considered. It is established, that on the basis of similarity in their petrographic and petrochemical features granitoids of the area can be related to single complex. Features of ore mineralization are defined by both composition of granitoids (Sgranites) after which rare-metal pegmatites are formed and intensity of superimposed metasomatic alterations.

Main minerals-concentrators of Ta and $\mathrm{Nb}$ mineralization in granitic pegmatites and metasomatites are represented by minerals of three isomorphic series - columbite-tantalite $(\mathrm{Fe}, \mathrm{Mn})(\mathrm{Nb}, \mathrm{Ta}, \mathrm{Ti})_{2} \mathrm{O}_{6}$, ilmenorutile-struverite $(\mathrm{Ti}, \mathrm{Nb}, \mathrm{Ta}) \mathrm{O}_{2}$ and pyrochlore-microlite $(\mathrm{Ca}, \mathrm{Na})_{2} \mathrm{Ta}_{2} \mathrm{O}_{6}(\mathrm{O}, \mathrm{B}, \mathrm{OH}, \mathrm{F})$. Depending on geological setting such ore minerals as tapiolite, ixiolite, cassiterite, uraninite, nigerite, gahnite are commonly found in association with these minerals.

Chemical composion of tantalo-niobates sampled from ore-bearing pegmatites and metasomatites is investigated by microprobe analysis. Most minerals of columbite-tantalite series are characterized by distinct and rhythmic internal zonality and contrasting mosaic structure which are related to considerable heterogeneities of their chemical composition. Within one aggregate mineral phases with wide range of values - from 9,80 to $71,0 \%$ for $\mathrm{Ta}_{2} \mathrm{O}_{5}$ and from 10,6 to $70,1 \%$ for $\mathrm{Nb}_{2} \mathrm{O}_{5}$-are established. Among minerals ferruginous varieties which composition relates to Fe-columbite-tantalites $\left(\mathrm{Nb}_{2} \mathrm{O}_{5} / \mathrm{Ta}_{2} \mathrm{O}_{5}=1-1,2 ; \mathrm{FeO} / \mathrm{MnO}=2,5-6\right)$ prevail. Columbite-tantalites are characterised by high contents of admixture elements present (\%): $\mathrm{TiO}_{2}-$ to 5,$88 ; \mathrm{WO}_{3}-$ to 3,70; $\mathrm{SnO}_{2}-$ to 9,20; $\mathrm{Sc}_{2} \mathrm{O}_{3}-$ to 5,40 . Scandium ores occur as scandium-rich minerals that are mostly confined to the minerals of columbite-tantalite series found in Polohivka ore field. On the Ukrainian Shield high contents of $\mathrm{Sc}_{2} \mathrm{O}_{3}$ in tantalo-niobates are established for the first time.

Minerals of ilmenorutile-struverite series do not quantitatively yield to minerals of columbite-tantalite series. For minerals of this series $\mathrm{Nb}_{2} \mathrm{O}_{5} / \mathrm{Ta}_{2} \mathrm{O}_{5}$ ratio varies in the range of 0,6-1,4. Among characteristic admixture-elements are prevailed (\%): $\mathrm{SnO}_{2}-$ to 3,1, $\mathrm{V}_{2} \mathrm{O}_{5}-$ to 5,05 ; $\mathrm{FeO}$ - to 11,51, $\mathrm{Cr}_{2} \mathrm{O}_{3}-$ to 1,20. Minerals of pyrochlore-microlite series are of subordinate importance.

For the first time by results of U-Pb dating of columbite-tantalites from Mostove ore manifestation (Shpoliano-Tashlyk area) the age of Ta-Nb mineralization is established to be about $1965 \pm 25$ million years.
\end{abstract}

Keywords: Rare-metal pegmatites, Ta-Nb mineralization, Ukrainian Shield.

Introduction. Shpoliano-Tashlyk ore area became known after intensive prospection and exploration works carried out by local geological enterprises, SE "Kirovgeology" and "Centergeology" during 1980-90, As the results of these works two ore-bearing fields, Polohivka and Stankuvatka, with general specialisation on rare metals ( $\mathrm{Li}, \mathrm{Rb}, \mathrm{Cs}, \mathrm{Be}, \mathrm{Ta}, \mathrm{Nb}, \mathrm{Sn})$ are discovered and outlined within the western area of Ingul megablock of Ukrainian Shield (Fig. 1) (Ivanov et al., 2000).

Polohivka ore field is found to be confined to the western flank of Korsun-Novomirgorod pluton that is comprised by anortosite - rapakivi granite associations. Several swarms of pegmatites with associated rare-metal mineralisation are found here, within the marginal area of Polohivka ore field. This field includes Polohivka deposit of lithium that is situated at the immediate proximity of the KorsunNovomirgorod pluton and Petroostrivske ore site. The Petroosrivske site itself is situated to the northwest of the Polohivka deposit and, in contrast, shows wide abundance of predominantly $\mathrm{Ta}-\mathrm{Nb}$ mineralization. It includes Mostove deposit of tantalum and some small manifestations of the similar mineralogical type - Kopanky, Vys, Yaroshivka. (Nechaev et al., 1991; Eremenko et al., 1996).

Problem statement. Mostove ore deposit is still nonsufficiently explored but, at present, it is treated as the most perspective ore-bearing deposit with economic $\mathrm{Ta}$ mineralization among those recently found within Ukrainian Shield. Based on the deep drilling data this deposit might be described as ore-bearing system that includes several ore bodies (ore veins) which form cross-cut structure (ore column) in the central part of the deposit (Eremenko et al., 1996; Gursky et al., 2005). The most of rich ore intervals (that is evidenced by drill core samples) are comprised by albitemicrocline metasomatites and intensively altered turmalinemuskovite pegmatites that commonly host associated sillimanite, cordierite and apatite. Country rocks of metamorphic origin are represented by biotite, garnet-biotite and cordierite-biotite gneisses with associated sillimanite.

Dessiminated type mineralization occur as lense-like bodies, nests and zones of impregnated ores. The richest ore intervals $\left(\mathrm{Ta}_{2} \mathrm{O}_{5}\right.$ up to $0,04 \%$ and $\mathrm{Nb}_{2} \mathrm{O}_{5}$ up to $\left.0,02 \%\right)$ are found to be confined to metasomatically altered granites that are pegmatitic in appearance as well as rare-metal pegmatites and albite-microcline veins. In most cases ore mineralization itself is mostly controlled by faults and metasomatic zones (greisens) which are commonly formed at the exocontact areas of granite massifs. $\mathrm{Nb}-\mathrm{Ta}$ mineralization commonly shows superimposed nature and rarely might be found at the margin areas of early formed lithium-rich pegmatites.

Stankuvatka ore field includes Lipnazhka and Novoodeske rare-metal manifestations and lithium deposits of Stankuvatka, Nadezhda. They are spatially loccalized within the west and northwest exocontacts of Lipniazhka granite massif (Fig. 1). Stankuvatka lithium deposit does not show high concentration of $\mathrm{Nb}$ and $\mathrm{Ta}$, with average values reaching $0,015 \%$ for $\mathrm{Ta}_{2} \mathrm{O}_{5}$ and $0,015 \%$ for $\mathrm{Nb}_{2} \mathrm{O}_{5}$. The most of rich sites of $\mathrm{Ta}-\mathrm{Nb}$ mineralization are confined to veins of metasomatically altered pegmatitic granites and albite-microcline metasomatites. Ore mineralization is characterised by dessiminated nature when most tantaloniobites occurred as accessory minerals in metasomatically altered (greizenised) pegmatites spatially confined to exocontact zones of Lipniazhka granite massif. Majority of ore bodies and manifestations are characterized by distinct internal ore zonality. Petalite and petalite-spodumene associations are found to be confined to the central parts of ore bodies as well as tantalo-niobites occur as confined to zones of thinning of pegmatitic veins. In general, high concentration of tantalum-niobate mineralization are found in thinning zones of lithium pegmatites and superimposed 
metasomatites that are spacially (and genetically) associated with them.

General geological setting. The Shpoliano-Tashlyk ore area is situated in the northwest of Ingul megablock where it occupies the northern part of so-called Bratsky synclinorium. The synclinorium itself might be traced as uniform regionalscale structure (belt) that strikes in submeridional direction along western margin of intrusive-magmatic system comprised by differently aged structures - KorsunNovomyrgorod anortosite-rapakivi-granite pluton and Novoukrainka diorite-monzonite massif. From the southwest, synclinorium is bordered by exposed structures of granulitic basement - Golovanivka zone (block). The overall submeridional symmetry of the Bratsky synclinorium is additionally marked by a number of granite massifs of ultrametamorphic origin that are elongated in the same direction and S-N strike of linear folding of relic metamorphic rocks. Structurally, the synclinorium is interpreted as regional-scale epicratonic (as well as epi-Archean) depression that hosts rock association of Proterozoic age. Geological section generally includes two separate stratigraphic units that show distribution of regional scale. The first unit includes rocks of Kamenno-Kostuvatka suite which are widely distributed within the southern area of the Bratsky sinclinorium. This suite includes pyroxene gneisses, crystalloschists, garnet-bioitite, garnet-cordierite-biotite, graphite-biotite gneisses, calciphyres and skarns. Rocks of the second unit are mostly abundant in the northern area of the Bratsky synclinorium and are presented by biotite, graphite-biotite, amphybole-biotite, graphite-garnetamphibole gneisses that are rhythmically intercalated with layers of amphibolites, quartzites and ultramaphic rocks. All this rock associations are combined into the single Roschahivka suite. Metamorphic rocks of both suites are intensively changed by ultrametamorphic alterations. They are deeply silicified and thinly-layered with formation of migmatites. Coarse-grained biotite granites of pegmatitic nature are abundant here and mapped mostly everywhere. Rhythmic interlayerring of metamorphic rocks is additionally marked by layers of metaultramafic rocks which are commonly found within ore-bearing zones.

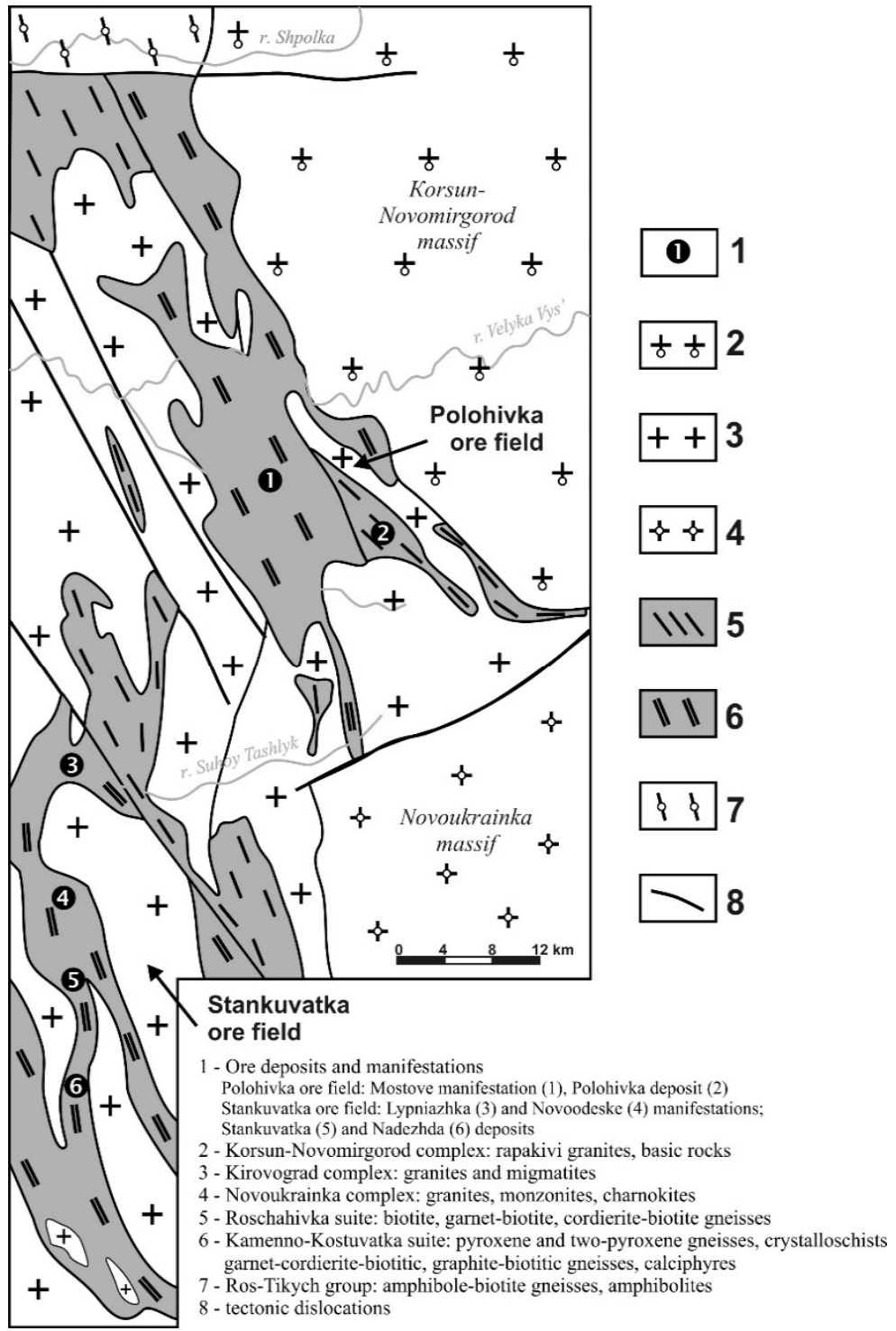

Fig. 1. Location scheme of ore fields, deposits and manifestations of Shpoliano-Tashlyk ore area

Rare-metal pegmatites and metasomatites are commonly found to be confined to the exocontacts of granite massifs which are widely abundant within Shpoliano-
Tashlyk ore area - Novopavlivka, Mykhaylivka, Berezivka, Lipniazhka, Doropheivka, Yaroshivka massifs.

All these granites are formed at processes of ultrametamorphic alterations of rocks of Kamenno- 
Kostuvatka and Roschahivka suites and are related to Kirovograd complex, which is treated as typical for the whole area of Ingul megablock. At the same time, granitoids of the western area of Ingul megablock show some features that distinguish them from possible analogues distributed in the eastern and central areas of the megablock. This fact has caused some early proposals to distinguish granitoids of Bratsky synclinorium into the separate Voznesensky complex (Scherbakov, 2005).

It is necessary to note, that among numerous schemes granite classification, the most suitable as to metallogenic forecast is still remained the scheme proposed by Chappel and White (Chappell et al., 2001). According to this scheme, granites are classified into two different I- and S- types that are formed as a result of ultrametamorphic alterations (anatexis) of mostly igneous (I) or sedimentary (S) protolyths. This scheme broadly corresponds to local scheme proposed earlier by Shcherbakov (Scherbakov, 2005) according to which granites of Ukrainian Shield were classified into apobasic (I) and apopelitic (S) types. Sedimentary type granites that are formed after primarysedimentary rocks can inherit high contents of fluxing components ( $\mathrm{B}, \mathrm{P}, \mathrm{F}$ etc.). These components can essentially lower the temperature of crystallization and make S-type granites especially favorable for formation of pegmatite-generating melts enriched in rare lithophile elements ( $\mathrm{Li}, \mathrm{Cs}, \mathrm{Ta}, \mathrm{Nb}$ and others).

Apopelitic type granites are widely abundant within Shpoliano-Tashlyk area. Here, they are characterized by common presence of biotite, garnet or cordierite as rockforming minerals as well as ilmenite and uraninite as typical accessory minerals. Some varieties of these granites are predominantly peraluminous $\left(\mathrm{Al}_{2} \mathrm{O}_{3}>\mathrm{Na}_{2} \mathrm{O}+\mathrm{Ka} 2 \mathrm{O}+\mathrm{CaO}\right)$, enriched in potassium over sodium and characterized by high silica content $\left(64-77 \% \mathrm{SiO}_{2}\right)$. These granites as well as associated pegmatites and metasomaties are potentially ore-bearing.

Nature of Ta-Nb mineralization. Deposits and numerous ore manifestations of rare metals of ShpolianoTashlyk ore area are formed in rather similar geologic-andtectonic settings and consequently show common geologic features. These features are manifested in both mineralogy of country rocks and ore mineral associations that comprise most occurrences of $\mathrm{Ta}-\mathrm{Nb}$ mineralization. Main concentrators of $\mathrm{Ta}$ and $\mathrm{Nb}$ are represented by minerals of three isomorphic series - columbite-tantalite $(\mathrm{Fe}, \mathrm{Mn})(\mathrm{Nb}, \mathrm{Ta}, \mathrm{Ti})_{2} \mathrm{O}_{6}$, ilmenorutile-struverite $(\mathrm{Ti}, \mathrm{Nb}, \mathrm{Ta}) \mathrm{O}_{2}$ and pyrochlore-microlite $(\mathrm{Ca}, \mathrm{Na})_{2} \mathrm{Ta}_{2} \mathrm{O}_{6}(\mathrm{O}, \mathrm{B}, \mathrm{OH}, \mathrm{F})$ (Nechaev et al., 1992; Grinchenko et al., 2008).

Minerals of columbite-tantalite series are mostly abundant in Shpoliano-Tashlyk ore area. From 60 to $80 \%$ of niobium and tantalum are concentrated in minerals of this series. Ore minerals of columbite-tantalite series only sometimes show less abundance in comparison to minerals of ilmenorutile-struverite series. In many cases it depends on composition of host rocks and degree of their alterations by superimposed metasomatic processes.

The most of $\mathrm{Ta}-\mathrm{Nb}$ minerals of the series occur as impregnated idiomorphic aggregates or form intergrowths with other minerals (cassiterite, ilmenorutile, microlite, and uraninite). Electronic microscope investigations indicate steady presence of inner zonation and mosaic structure of columbite-tantalites. Typical feature is variable chemical composition which is observed both at macroscale (ore body) and microscale (single grain) levels. Several mineral phases with wide range of $\mathrm{Ta}_{2} \mathrm{O}_{5}(9,80$ to $71,0 \%)$ and $\mathrm{Nb}_{2} \mathrm{O}_{5}$ $(10,6$ to $70,1 \%)$ can be established within the single ore mineral grain. Microprobe data indicate predominance of ferruginous varieties ( $\mathrm{FeO} / \mathrm{MnO}=2,80-6,56$ in average) of columbite-tantalites (Fig. 2).

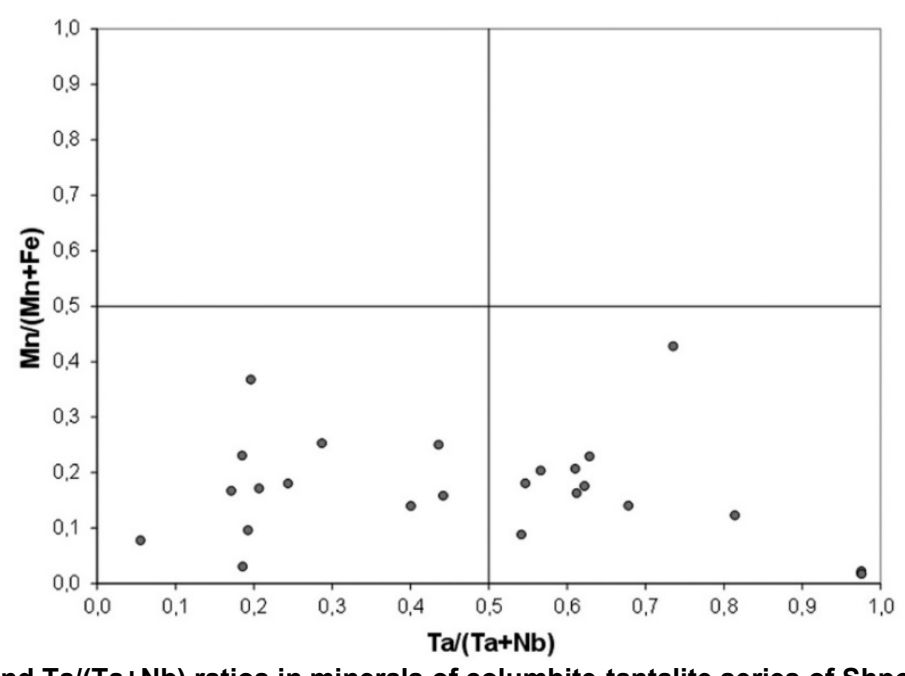

Fig. 2. $\mathrm{Mn} /(\mathrm{Mn}+\mathrm{Fe})$ and $\mathrm{Ta} /(\mathrm{Ta}+\mathrm{Nb})$ ratios in minerals of columbite-tantalite series of Shpoliano-Tashlyk ore area

Minerals of columbite-tantalite series are also characterised by high contents of admixture elements present (\%): $\mathrm{Ti}\left(\mathrm{TiO}_{2}\right.$ up to 5,88$), \mathrm{W}\left(\mathrm{WO}_{3}\right.$ up to 3,70$), \mathrm{Sn}$ $\left(\mathrm{SnO}_{2}\right.$ up to 9,20$)$ and even $\mathrm{Sc}\left(\mathrm{Sc}_{2} \mathrm{O}_{3}\right.$ up to 5,40$)$.

Titanium is a characteristic admixture-element in minerals of this series. Occurrence of titanium in the structure of tantaloniobates is caused by close affinity of their crystallochemical properties. Contents of titanium varies from 0,5 to $2 \%$ in average, with the highest contents $(5,88 \%)$ being established for columbite-tantalites of Stankuvatka deposit.

Tin is also found as present in composition of minerals of this series and rarely its content can reach $9,40 \%$. At the same time, most columbite-tantalites are characterised by rather low contents of tin (0,3-1\%). Abnormal high contents of tin are found in ixiolite (disordered phase of tantaloniobates) that is sampled from muscovitized two-feldspaar pegmatite of Yaroshivka ore manifestation.

Tungsten is found as present in all mineral varieties of columbite-tantalite series. The contents of tungsten found in tantalites show considerably the average values (up to $3,30 \%)$. At the same time columbite with low tantalum show essentially low contents of tungsten $(0,1-1 \%)$.

Scandium is found in minerals of tantalite-columbite series of Shpolano-Tashlyk ore area for the first time. Ore minerals of Polohivka manifestation are mostly scandiumbearing with scandium content reaching high (up to 
economic) ore grade values. Sc is established in practically all varieties of tantalo-niobates with scandium content ranging from 0,1 to $1 \%$.

Other admixuters in minerals of columbite-tantalite group are represented by magnesium, calcium, rare earth elements and uranium, with their contents that do not exceed $1 \%$.

Minerals of ilmenorutile-struverite series are mainly occurred in the zones of metasomatic alterations of pegmatitic granites and rare-metal pegmatites. On the distribution they take the second place after columbitetantalites, and sometimes occur as the main mineralconcentrators of $\mathrm{Nb}$ and Ta mineralisation.

For most ore objects the occurrence and nature of ilmenorutile-struverite mineral series are mostly similar to that of columbite-tantalites. Crystallochemically minerals of this series are interpreted as $\mathrm{Fe}(\mathrm{Nb}, \mathrm{Ta})_{2} \mathrm{O}_{6}$ solid solutions formed in $\mathrm{TiO}_{2}$ matrix. Natural intergrowths between these two mineralogical varieties are commonly observed.

For the first time high concentrations of $\mathrm{Ti}-\mathrm{Nb}-\mathrm{Ta}$ mineralization were established in natural outcrops situated at the flank of Lipnizhka ore manifestation, and have been traced in similar pegmatites at the sections of deep boreholes. Aggregates of subgraphic intergrowths of these minerals are constantly found as desseminated impregnations in dark grey quartz among cataclised formations of muskovite-spodumene-petalite pegmatites. The ilmenorutile is the main mineral-concentrator of $\mathrm{Nb}$ and $\mathrm{Ta}$ in biotite-apatite-cordierite apogabbroic metasomatites. Here it forms impregnated grains of subidiomorphic habit and occur in association with ilmenite, pyrrhotite, pentlandite, niccolite and gersdorfite. This type of $\mathrm{Ta}-\mathrm{Nb}$ mineralization is characterised by predominance of ilmenorutile over struverite. According to the microprobe analysis minerals of this series show $\mathrm{Nb}_{2} \mathrm{O}_{5} / \mathrm{Ta}_{2} \mathrm{O}_{5}$ values ranging from 0,6 to 1,4 . Among admixture elements found are (\%) $\mathrm{Sn}\left(\mathrm{SnO}_{2}\right.$ up to 3,1$), \mathrm{V}\left(\mathrm{V}_{2} \mathrm{O}_{5}\right.$ up to 5,05$)$, $\mathrm{Fe}$ (up to $11,51)$ and $\mathrm{Cr}\left(\mathrm{Cr}_{2} \mathrm{O}_{3}\right.$ up to 1,20$)$.

Minerals of pyrochlore-microlite series_are mostly represented by microlite which occur in association with tantalo-niobates and cassiterite. In most cases, microlite is formed as a result of superimposed alteration of tantaloniobates and tantalum-rich cassiterites. Mineralogically segregations are represented by veinlet and net-like patterns. Under ore microscope microlites are found as lightbrown spongy-like pseudomorphoses $(0.1$ to $0,3 \mathrm{~mm}$ in diameter) formed after tantalite minerals.

Microlite is characterised by complex and heterogenic structure. It commonly includes such element as calcium, titanin, tin, aluminium and uranium in its composition. $\mathrm{Ta}_{2} \mathrm{O}_{5} / \mathrm{Nb}_{2} \mathrm{O}_{5}$ ratio varies within the range of 2,5 to 6,9 . Microlites collected from spodumene-albitite pegmatites of Stankuvatka deposit show essentially high values of tungsten and tin.

Besides typical Ta-Nb minerals described above, rare metal pegmatites include other ore-mineral phases that contain $\mathrm{Ta}$ and $\mathrm{Nb}$. They are represented by such varieties as tapiolite $\mathrm{FeTa}_{2} \mathrm{O}_{6}$, ixiolite $(\mathrm{Nb}, \mathrm{Ta}, \mathrm{Sn}, \mathrm{Fe}, \mathrm{Mn}, \mathrm{Ti})_{4} \mathrm{O}_{8}$ and some other non-precisely identified mineralogical phases of tantalo-niobates. Among other minerals found as closely associated with different series of $\mathrm{Ta}$ and $\mathrm{Nb}$ minerals are cassiterite, nigerite, gahnite, uraninite, chrysoberyl, stannite, sphalerite and chalcopyrite.

Age of ore mineralization of rare-metal pegmatites of Shpoliano-Tashyk ore are under discussion during the long period of time. Difficulties in determination of the age of raremetal mineralisation are caused mainly by absence in their composition of so-called minerals-geochronometers (zircon or monazite) and multistage nature of rock formation and ore mineralization occurrences.
Some researchers followed the idea, that age of formation of rare-metal pegmatites of Polohivka ore field should be coeval to the age of of Korsun-Novomirgorod pluton intrusion (Bezvinny, 2005). The age of rapakivi granites of this pluton is dated as 1750 million years. (Esypchuk et al., 2004). At the same time, some metallogenic interpretations treat hypothetical dating of 2,3 billion years, obtained early by $\mathrm{Pb}$ $\mathrm{Pb}$ method (Eremenko et al., 1996), as possible age of raremetal pegmatites. Age dating at 2,0 billion years obtained for granitoids of Kirovograd complex (Shcherbak et al., 1995) is interpreted as the age of regional scale ultrametamorphic alterations of primary gneisses. It was assumed that pegmatites formed early at 2.3 billion years might be intensively altered by the subsequent ultrametamorphic processes. (Ivanov et al., 2001).

For the first time, based on the results of direct determination of $\mathrm{U}-\mathrm{Pb}$ ratios in columbite-tantalites collected from Mostove ore manifestation, the age of $\mathrm{Ta}-\mathrm{Nb}$ mineralization is established to be about $1965 \pm 25$ million years. At the same time, based on microprobe investigations and calculations according to CHIME method (Suzuki et al., 2008) the age of uraninite associated with tantalo-niobate minerals is estimated to be about 1925 million years.

Conclusions. Granites, genetically associated pegmatites and superimposed metasomatites are widely distributed within Shpoliano-Tashlyk ore area in the western part of Ingul megablock, Ukrainian Shield. Their Petrochemical and geochemical features of these rocks can indicate their potential ore-bearingness as to rare-metal mineralization.

Numerous deposits and ore manifestations of $\mathrm{Ta}-\mathrm{Nb}$ mineralizations of ore area were formed in similar geologicand-tectonic setting and have many the common features as in chemical composition of host rocks and associations of ore minerals. Mineralogical composition of $\mathrm{Ta}-\mathrm{Nb}$ mineralization is defined by isomorphic series of minerals represented by columbite-tantalite and ilmenorutilestruverite series. Moreover ore paragenesises sometimes includes other $\mathrm{Ta}-\mathrm{Nb}$ minerals such as microlite, tapiolite, ixiolite and non-identified phase of tantalo-niobates. According to microprobe analyses minerals of columbitetantalite group contain $\mathrm{Ta}$ and $\mathrm{Nb}$ in approximately equal amounts. Typical admixture-elements in minerals of this given group are represented by (\%): $\mathrm{TiO}_{2}-$ to 5,$88 ; \mathrm{WO}_{3}=$ to 3,$70 ; \mathrm{SnO}_{2}=$ to 9,$20 ; \mathrm{Sc}_{2} \mathrm{O}_{3}-5,40$. High contents of scandium in tantalo-niobates are established in Ukrainian Shield for the first time.

Manifestations of Ta-Nb mineralization of ShpolianoTashyk ore area are unique high-grade ore objects specialised on tantalum on the Ukrainian Shield. Therefore, their studying has high economic importance as to the prospects of development of raw-material base of tantalum and other rare elements (Rb, Cs, Nb, Sn, Li, W, Sc). Potential prospections of these objects are also substantiated by their geological and mineralogical-andgeochemical features that are widely similar to those established as typical classical (world-known) deposits of rare-metal pegmatites of LCT (Li-Cs-Ta) type, such as Greenbushes (Australia), Tanco (Canada). (Cerny, 1989; Cerny et al., 2005).

For the majority of rare-metal granitic pegmatites of this type their spatial and genetic relations with granites of "sediment-type" origin (S-type) are established. They are formed as a result of anatexic alteration of primarysedimentary strata. Inherited high contents of such fluxing elements as $\mathrm{B}, \mathrm{P}, \mathrm{Li}$ and $\mathrm{F}$ can cause these rock associations to be favorable on formation of rare-metal pegmatites. One more characteristic feature of LCT pegmatites is the fact, that host rocks around these pegmatites are commonly metasomatised. The dissemination of alkaline elements in 
metasomatic aureoles around these pegmatites might be used as the important criterion for their possible prospection and exploration. Lithium anomalies form the widest aureoles adjacent to pegmatites and can exceed more than 100 meters in size. (Cerny, 1989).

It is necessary to note, that granite pegmatites of Shpoliano-Tashlyk ore area have also experienced intensive metamorphic and superimposed metasomatic alteration (Ivanov et al., 2001). Some ore sites show so high abundance of metasomatites that some researchers even treat metasomatic alterations as the key factor of formation of rare-metal mineralization (Bezvinny, 2005). At the same time the results of age determination for $\mathrm{Ta}-\mathrm{Nb}$ mineralization of Shpoliano-Tashlyk ore area obtained on columbite-tantalites and associated uraninite have shown possible ages of formation as 1965 and 1925 million years, accordingly. These dating might be broadly correlative with the age of formation of ultrametamorphic granitoids of Kirovograd complex.

Список використаних джерел

Безвинний, В.П. (2005). Рідкіснометалеве та золоте зруденіння і метасоматичні процеси Петроострівського рудного поля. Збірник наукових праць УкрДГРІ, 1, 82-84

Гурский, Д.С., Есипчук, К.Е., Калинин, В.И., Кулиш, Е.А., Нечаев, С.В. Третьяков, Ю.И., Шумлянский, В.А. (Ред.) (2005). Металлические и неметалические полезные ископаемые Украины. Том. 1. Металлические полезные ископаемые. Киев; Львов: Изд-во "Центр Европы".

Еременко, Г.К., Иванов, Б.Н., Белых, Н.А., Кузьменко, А.В., Макивчук, О.Ф. (1996). Минералогические особенности и условия образования литиевых пегматитов Кировоградского блока (Украинский шит). Минералогический журнал, 1(18), 48-57.

Єсипчук, К.Ю., Бобров, О.Б., Степанюк, Л.М., Щербак, М.П. (2004.) Кореляційна хроностратиграфічна схема раннього докембрію Українського щита (пояснювальна записка). Київ: Изд-во "УкрДГРІ".

Іванов, Б.Н., Маківчук, О.Ф., Бугаєнко, В.М., Лисенко, В.В., Єрьоменко, Г.К. (2000). Основні типи рідкіснометальних родовищ і рудопроявів в західної частини Кіровоградського блоку. Збірник наукових праць УкрДГРІ, 1-2, 101-107

Іванов Б.Н., Лисенко, В.В., Маківчук, О.Ф., Єременко, Г.К., Бугаєнко, В.М., Бондаренко, С.М. (2001). Екзоконтактові метасоматити літієвих гранітних пегматитів Шполяно-Ташлицького рідкіснометального рудного району. Мінеральні ресурси, 4, 11-13.

Нечаев, С.В., Макивчук, О.Ф., Белых, Н.А., Иванов, Б.Н., Кузьменко, А.В., Прытков, Ф.Я., Бугаенко, В.Н., Семка, В.А. (1991). Новый редкометальный район Украинского щита. Геологический журнал, 4, 119-122.

Нечаев, С.В., Бондаренко, С.Н., Нечаев, С.Вл. (1992). Танталониобаты из пегматитов центральной части украинского щита. Геологический журнал, 3, 85-88.

Щербак, Д.Н., Пономаренко, А.Н., Макаренко, И.Д. (1995). Геохронология гранитоидов Ингуло-Ингулецкого мегаблока Украинского щита. Геохимия и рудообразование, 21, 74-88.

Щербаков, И.Б. (2005). Петрология Украинского щита. Львов: Изд-во "ЗУКЦு".

Cerny, P. (1989). Rare-element granitic pegmatites. Part II: regional to global environments and petrogenesis. Geoscience Canada, 2(18), 68-81.
Cerny, P., Ercit, T.S. (2005). The classification of granitic pegmatites revisited. Canadian Mineralogist, 43, 2005-2026.

Chappell, B.W., White A.J.R. (2001). Two contrasting granite types: 25 years later. Australian Journal of Earth Sciences, 48, 489-499.

Grinchenko, O., Bondarenko, S., Syomka, V., Ivanov, B., Kanunikova, L. (2008). Tantalum-niobates of orogenic rare-metal deposits in western part of the Ukrainian Shield (typochemistry and distributional patterns). Proc. XXXIII International Geological Congress, 6-14 August, Oslo, Norway, 234.

Suzuki, K., Kato, T. (2008). CHIME dating of monazite, xenotime, zircon and polycrase: Protocol, pitfalls and chemical criterion of possibly discordant age data. Gondwana Research, 14, 569-586.

\section{References}

Bezvinny, V.P. (2005). Rare-metal and gold mineralization and metasomatic processes of Petroostrivske ore field. Scientific proceedings of UkrSGRI, 1, 82-84. [in Ukrainian].

Cerny, P. (1989). Rare-element granitic pegmatites. Part II: regional to global environments and petrogenesis. Geoscience Canada, 2 (18), 68-81.

Cerny, P., Ercit, T.S. (2005). The classification of granitic pegmatites revisited. Canadian Mineralogist, 43, 2005-2026.

Chappell, B.W., White, A.J.R. (2001). Two contrasting granite types: 25 years later. Australian Journal of Earth Sciences, 48, 489-499.

Eremenko, G.K., Ivanov, B.N., Belych, N.A., Kuzmenko, A.V., Makivchuk, O.F. (1996). Mineralogical features and conditions of formation of lithium pegmatites of the Kirovograd block (Ukrainian Shield). Mineralogical journal, 1(18), 48-57. [in Russian].

Esypchuk, K.Yu., Bobrov, O.B., Stepanjuk, L.M., Scherbak, M.P. (2004). Correlative chronostratigraphic scheme of early Precambrian of the Ukrainian Shield (explanatory note). Kyiv: Publishing house "UkrSGRI". [in Ukrainian].

Grinchenko, O., Bondarenko, S., Syomka, V., Ivanov, B., Kanunikova, L. (2008). Tantalum-niobates of orogenic rare-metal deposits in western part of the Ukrainian Shield (typochemistry and distributional patterns). XXXIII International Geological Congress, 6-14 August, Oslo, Norway, 234.

Gursky, D.S., Esipchuk, K.E., Kalinin, V.I., Kulish, E.A., Nechaev, S.V. Tretiakov, Yu.I., Shumliansky, V.A. (Eds.) (2005). Metallic and non-metallic minerals of Ukraine. Issue.1. Metallic minerals. Kyiv; Lviv: Publishing house "Center of Europe" [in Russian].

Ivanov, B.N., Makivchuk, O.F., Bugaenko, V.M., Lysenko, V.V., Eremenko, G.K. (2000). Main types of rare-metal deposits and ore manifestations in western part of the Kirovograd block. Scientific proceedings of UkrSGRI, 1-2, 101-107. [in Ukrainian].

Ivanov, B.N , Lysenko, V V Makivchuk, O.F, Eremenko, G.K., Bugaenko, V.M., Bondarenko, S.M. (2001). Exocontact metasomatites of lithium granitic pegmatites of Shpoliano-Tashlyk rare-metal ore area. Mineral resources of Ukraine, 4, 11-13. [in Ukrainian].

Nechaev, S.V., Makivchuk, O.F., Belyh, N.A., Ivanov, B.N., Kuzmenko, A.V., Prytkov, F.Ya., Bugaenko, V.N Semka, V.A (1991) New rare-metal area of the Ukrainian Shield. Geological Journal, 4, 119-122. [in Russian].

Nechaev, S.V., Bondarenko, S.N., Nechaev, S.VI. (1992).Tantalo-niobates from pegmatites of central areapart of the Ukrainian Shield. Geological Journal, 3, 85-88, 1992. [in Russian].

Scherbakov, I.B. (2005). Petrology of the Ukrainian Shield. Lviv: Publishing house "ZUKC". [in Russian]

Shcherbak, D.N., Ponomarenko, A.N., Макаrenko, I.D. (1995). Geochronology of granitoids of Ingulo-Ingulets megablock of the Ukrainian Shield. Geochemistry and ore formation, 21, 74-88. [in Russian].

Suzuki, K., Kato, T. (2008). CHIME dating of monazite, xenotime, zircon and polycrase: Protocol, pitfalls and chemical criterion of possibly discordant age data. Gondwana Research, 14, 569-586.

Надійшла до редколегії 23.05.18

О. Грінченко1, канд. геол-мінералог. наук, доц.,

E-mail: alexgrin@univ.kiev.ua

С. Бондаренко ${ }^{2}$ канд. геол. наук, старш. наук. співроб.

E-mail: sbond@igmof.gov.ua

Т. Мірончук ${ }^{1}$, канд. філол. наук, доц.

E-mail: tatianakiev99@gmail.com

"Київський національний університет імені Тараса Шевченка, ННI "Інститут Геології"

вул. Васильківська, 90, м. Київ, 03022, Україна

Інститут геохімії, мінералогії та рудоутворення НАН України

пр. Палладіна, 34, м. Київ-142, 03680, Україна

\section{ГРАНИТОЇДИ, РІДКІСНОМЕТАЛІЧНІ ПЕГМАТИТИ ТА ТА-NВ МІНЕРАЛІЗАЦІЯ ШПОЛЯНО-ТАШЛИЦЬКОГО РУДНОГО РАЙОНУ (ІНГУЛЬСЬКИЙ МЕГАБЛОК, УКРАЇНСЬКИЙ ЩИТ)}

Розглянуто речовинний склад гранітів, споріднених з ними пегматитів і накладених метасоматитів розповсюджених у межах Шполяно-Ташлицького рудного району (Інгульский мегаблок). Установлено, що гранітоїди району на підставі подібності їхніх петрографічних і петрохімічних особливостей можуть бути віднесені до єдиного комплексу. Особливості прояву рудної мінералізації визначаються як складом гранітоїдів (S-гранітu), по яких формуються рідкіснометалічні пегматити, так і інтенсивністю прояву накладених метасоматичних перетворень.

Головні мінерали-концентратори Та і $\mathrm{Nb}$ мінералізації в гранітних пегматитах і метасоматитах представлені мінералами трьох ізоморфних рядів - групи колумбіт-танталіту $(\mathrm{Fe}, \mathrm{Mn})(\mathrm{Nb}, \mathrm{Ta}, \mathrm{Ti})_{2} \mathrm{O}_{6}$, ільменорутил-стрювериту (Ti,Nb,Ta) $\mathrm{O}_{2}$ та пірохлор-мікроліту $(\mathrm{Ca}, \mathrm{Na})_{2} \mathrm{Ta}_{2} \mathrm{O}_{6}(\mathrm{O}, \mathrm{B}, \mathrm{OH}, \mathrm{F})$. Залежно від геологічної обстановки в асоціації з цими мінералами часто відмічаються такі рудні мінерали, як тапіоліт, іксіоліт, каситерит, уранініт, нігерит, ганіт. 
За допомогою мікрозондового аналізу було досліджено хімічний склад тантало-ніобатів з рудоносних пегматитів і метасоматитів. Мінерали групи колумбіт-танталіту показують внутрішню ритмічну зональність і контрастну мозаїчність, яка позв'язана зі значними неоднорідностями хімічного складу. У межах одного мінерального агрегату встановлюються фази із широким діапазоном значень - від 9,80 до 71,0 \% для $\mathrm{Ta}_{2} \mathrm{O}_{5}$ та від 10,6 до 70,1\% для $\mathrm{Nb}_{2} \mathrm{O}_{5}$. Серед мінералів переважають залізисті різновиди, які за складом відповідають Fe-колумбіт-танталітам ( $\left.\mathrm{Nb}_{2} \mathrm{O}_{5} / \mathrm{Ta}_{2} \mathrm{O}_{5}=1-1,2 ; \mathrm{FeO} / \mathrm{MnO}=2,5-6\right)$. Колумбіт-танталіти характеризуються високим вмістом елементівдомішок (\%): $\mathrm{TiO}_{2}$ - до 5,88; $\mathrm{WO}_{3}$ - до 3,70; $\mathrm{SnO}_{2}$ - до 9,20; $\mathrm{Sc}_{2} \mathrm{O}_{3}$ - до 5,40. Скандієносними виявилися переважно мінерали групи колумбіттанталіту Полохівського рудного поля. Високі концентрації $\mathrm{Sc}_{2} \mathrm{O}_{3}$ у тантало-ніобатах фіксуються на Українському щиті вперше.

Мінерали групи ільменорутил-стрюверіту кількісно не поступаються мінералам групи колумбіт-танталіту. Для мінералів даної групи значення відношення $\mathrm{Nb}_{2} \mathrm{O}_{5} / \mathrm{Ta}_{2} \mathrm{O}_{5}$ змінюються в діапазоні 0,6-1,4. Серед характерних елементів-домішок переважають (\%): SnO до 3,1, $\mathrm{V}_{2} \mathrm{O}_{5}$ - до 5,05; $\mathrm{FeO}$ - до 11,51, $\mathrm{Cr}_{2} \mathrm{O}_{3}$ - до 1,20. Мінерали групи пірохлор-мікроліту мають підпорядковане значення.

Уперше за результами U-Pb датування колумбіт-танталітів з рудопрояву Мостове (Шполяно-Ташлицький район) був визначений вік формування Ta-Nb мінералізації, який становить $1965 \pm 25$ млн років.

Ключові слова: рідкіснометалічні пегматити, Ta-Nb мінералізація, Український щит.

А. Гринченко ${ }^{1}$, канд. геол.-минералог. наук, доц.,

E-mail: alexgrin@univ.kiev.ua

С. Бондаренко ${ }^{2}$, канд. геол. наук., старш. науч. сотр.,

E-mail: sbond@igmof.gov.ua

Т. Мирончук ${ }^{1}$, канд. филол. наук, доц.,

E-mail: tatianakiev99@gmail.com

1Киевский национальный университет имени Тараса Шевченко, УнИ "Институт Геологии"

ул. Васильковская, 90, г. Киев, 03022, Украина

${ }^{2}$ Институт геохимии, минералогии и рудообразования НАН Украины

пр. Палладина, 34, г. Киев-142, 03680, Украина

\section{ГРАНИТОИДЫ, РЕДКОМЕТАЛЛИЧЕСКИЕ ПЕГМАТИТЫ И ТА-NВ МИНЕРАЛИЗАЦИЯ ШПОЛЯНО-ТАШЛЫЦКОГО РУДНОГО РАЙОНА (ИНГУЛЬСКИЙ МЕГАБЛОК, УКРАИНСКИЙ ЩИТ)}

Рассмотрен вещественный состав гранитов, родственных им пегматитов и метасоматоз, распространенных в пределах ШполяноТашлыцкого рудного района (Ингульский мегаблок). Установлено, что гранитоиды района на основании сходства их петрографических и петрохимических особенностей могут быть отнесены к единому комплексу. Особенности проявления рудной минерализации определяются как составом гранитоидов (S-граниты), по которым формируются редкометаллические пегматиты, так и интенсивностью проявления наложенных метасоматических преобразований.

Главные минералы-концентраторы Та и $\mathrm{Nb}$ минерализации в гранитных пегматитах и метасоматитах представлены минералами трех изоморфных рядов - группы колумбит-танталита (Fe,Mn)(Nb,Ta,Ti) $)_{6} \mathrm{O}_{6}$, ильменорутил-стрюверита (Ti,Nb,Ta) $\mathrm{O}_{2}$ и пирохлор-микролита $(\mathrm{Ca}, \mathrm{Na})_{2} \mathrm{Ta}_{2} \mathrm{O}_{6}(\mathrm{O}, \mathrm{B}, \mathrm{OH}, \mathrm{F})$. В зависимости от геологической обстановки в ассоциации с этими минералами часто отмечаются такие рудные минералы, как тапиолит, иксиолит, касситерит, уранинит, нигерит, ганит.

С помощью микрозондового анализа исследован химический состав тантало-ниобатов из рудоносных пегматитов и метасоматитов. Минералы группы колумбит-танталитов показывают внутреннюю ритмическую зональность и контрастную мозаичность, которая связана со значительными неоднородностями химического состава. В пределах одного минерального агрегата устанавливаются фазы с широким диапазоном значений - от 9,80 до 71,0 \% для $\mathrm{Ta}_{2} \mathrm{O}_{5}$ и от 10,6 до 70,1\% для $\mathrm{Nb}_{2} \mathrm{O}_{5}$. Среди минералов преобладают железистые разновидности, которые по составу отвечают Fе-колумбит-танталитам ( $\left.\mathrm{Nb}_{2} \mathrm{O}_{5} / \mathrm{Ta}_{2} \mathrm{O}_{5}=1-1,2 ; \mathrm{FeO} / \mathrm{MnO}=2,5-6\right)$. Колумбит-танталиты характеризуются высоким содержанием элементов-примесей (\%): $\mathrm{TiO}_{2}$ - до 5,88; $\mathrm{WO}_{3}$ - до 3,70; $\mathrm{SnO}_{2}-$ до 9,20; $\mathrm{Sc}_{2} \mathrm{O}_{3}-$ до 5,40. Скандиеносными оказались преимущественно минералы группы колумбит-танталита Полоховского рудного поля. Высокие концентрации Sс $\mathrm{O}_{3}$ в танталониобатах фиксируются на Украинском щите впервые. Минералы группы ильменорутил-стрюверита количественно не уступают минералам группы колумбит-танталитов. Для минералов данной группы значения отношения $\mathrm{Nb}_{2} \mathrm{O}_{5} / \mathrm{Ta}_{2} \mathrm{O}_{5}$ изменяются в диапазоне 0,6-1,4.

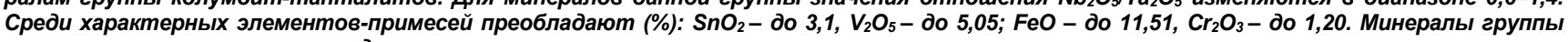
пирохлор-микролита имеют подчиненное значение.

Впервые по результами U-Pb датирования колумбит-танталитов из рудопроявления Мостовое (Шполяно-Ташлыцкий район) был определен возраст формирования Ta-Nb минерализации, который составляет $1965 \pm 25$ млн лет.

Ключевые слова: редкометаллические пегматиты, Та-Nb минерализация, Украинский щит. 